\title{
The impact of agriculture trade and exchange rate on economic growth of Pakistan: an NARDL and asymmetric analysis approach
}

\section{Imad Ali' ${ }^{1}$ Imran Khan ${ }^{1}$ Hashmat Ali $^{2}$ Khan Baz $^{3}$ Qiangqiang Zhang ${ }^{1}$ Ajab Khan ${ }^{2}$ Xuexi Huo ${ }^{*}$}

${ }^{1}$ Northwest Agriculture and Forestry University, College of Economics and management, Northwest A \& F University Yangling, Shaanxi 712100, Yangling, China. E-mail: xuexihuo@nwsuaf.edu.cn. *Corresponding author.

${ }^{2}$ Abbottabad University of Science and Technology Havelian, Khyber Pakhtunkhwa, Pakistan.

${ }^{3}$ China University of Geosciences Wuhan, School of Economics and Management, Wuhan, China.

ABSTRACT: This study contributes to the extant literature on the nexus among agriculture export, import exchange rate and economic growth in Pakistan. We used annual time series data for 1980-2017 and employ the Non-linear Autoregressive Distributed Lag (NARDL) model. The NARDL testing results affirms asymmetric co-integration among the variables. The study main results show: (i) Co-integration test for long run the positive shocks in export and import have positive significant while exchange rate has positive effect the economic growth. (ii) Co-integration test for short run the positive shocks in import has positive significant and while Export and exchange rate have negative significant effect on economic growth. The symmetrical results show: (i) Export has unidirectional granger causality (ii) Exchange rate has bidirectional granger causality (iii) Import has not ganger causality with economic growth. In addition, the results demonstrated that causality relationship can help out policy maker to design such policies which are useful to economic growth of Pakistan, which could further promote foreign trade to gain the maximum level of economic growth.

Key words: economic growth, agricultural export products, agricultural import products and exchange rate, NARDL, asymmetric relationship. Pakistan.

O impacto do comércio agrícola e da taxa de câmbio no crescimento econômico do Paquistão: uma abordagem de análise NARDL e assimétrica

RESUMO: Este estudo contribui para a literatura existente sobre o nexo entre exportação agrícola, taxa de câmbio de importação e crescimento econômico no Paquistão. Utilizamos dados de séries temporais anuais para 1980-2017 e empregamos o modelo Não-linear Autoregressive Distributed Lag (NARDL). Os resultados dos testes NARDL afirmam a co-integração assimétrica entre as variáveis. Os principais resultados do estudo mostram: (i) no teste de co-integração de longo prazo, os choques positivos nas exportações e importações têm uma significância positiva, enquanto a taxa de câmbio afeta positivamente o crescimento econômico; (ii) Teste de co-integração para curto prazo, os choques positivos nas importações são positivos significativos e, enquanto a exportação e a taxa de câmbio têm um efeito negativo significativo no crescimento econômico. Os resultados simétricos mostram: (i) a exportação tem causalidade unidirecional sobre o crescimento ; (ii) a taxa de câmbio tem causalidade bidirecional sobre o crescimento ; (iii) a importação não tem causalidade sobre o crescimento econômico. Além disso, os resultados demonstraram que a relação de causalidade pode ajudar o formulador de politicas a elaborar políticas úteis ao crescimento econômico do Paquistão, o que poderia promover ainda mais o comércio exterior para obter o nível máximo de crescimento econômico. Palavras-chave: crescimento econômico, produtos agrícolas de exportação, importação agrícola e taxa de câmbio, NARDL, relação assimétrica, Paquistão.

\section{INTRODUCTION}

Agriculture is the leading sector of Pakistan economy. This sector is of great importance for the economy of the country as $62 \%$ to $64 \%$ of total population living in rural areas, and is directly or indirectly engaged in agriculture activities. Agriculture segment contributes 19 percent to the GDP and employs about $42.3 \%$ of the total work force Pakistan Economic Survey (GOP, 2017a).
The contribution of agriculture export products in total country export is $19.4 \%$ and while agriculture import products has $15.71 \%$ in total import world integrated trade solution (WITS, 2017). Agriculture plays vital role in poverty alleviation, food insecurity and boosting up economic growth. A dynamic, profitable and improved agricultural sector can uplift the living style of the rural communities (GOP, 2017b). In Pakistan, the worth of agricultural import products has for all time been larger than the worth of 
agriculture export, which makes the country always remained trade deficit. The total agricultural export and agricultural import products in the year 2017 are $\$ 4243$ and $\$ 9020$ million respectively (WTO, 2017). For an agrarian country like Pakistan, it is crucial to think and consider that how to overcome this big trade deficit between the agricultural export and agricultural import. A healthy agriculture trade can play a key role in the economic development (SVATOS, et al., 2014).

In Pakistan the value of import has always been greater than the value of export (IRSHAD \& XIN, 2017). Due to this reason the balance of trade is not favorable of Pakistan. This has resulted in sustained fall in the external value of our currency, which means a steady increase in exchange rate over the whole period. Exchange rate is a macroeconomic factor which is influencing the foreign direct investment, foreign trade, unemployment, inflation and gross domestic product. While it is generally accepted that exchange rate is an important economic variable influencing export and import. Since the exchange rate of a currency has an effect on prices of agricultural products, it has also a great potential to play a big role in the competitiveness of the agriculture industry of a country; that is, there is a negative relationship between the value of a currency and the amount of exports. Unless domestic producers accept a lower price for their products, a strong currency of an exporter country will make exports more expensive for importers and make less competitive. Similarly, a weaker currency would increase exports and make domestic producers more competitive. This causality can also be observed more strictly in the commodities' futures markets. For the high international trade, price stability and suitable monetary policy the exchange rate regime are very important factors (FRIEDEN, et al., 2010). If there is positive links between exchange rate and gross domestic product, it clearly identified that the agriculture export products will be boost up Economic growth is the primary goal for policy makers (SOKOLOV, et al., 2011).

In the last four decade several developing countries economy have experienced the fast increased import and export to stimulate the economic growth. Since their independence, economically stable and less developed countries continuously striving to maintain sustainability in their economy and growth for long time. While, the trade policy play a key role in economic growth (RAZA, et al., 2015). The foreign trade can build and establishes the country's economic relationship with other countries. Economic growth is the basic element for uplifting life standard of people, to reduce poverty and unemployment in country. Economic and social researcher demonstrated that the sustainable economic growth facilitate better relief services and goods, including health and education which build societies (NOURZAD \& POWELL, 2003).

It is empirically confirmed that export led growth has effect on economy (BOLTHO, 1996; JAWAID \& RAZA, 2013). Developed and under developed countries economies could boost up through export growth. Till to date, scholars did not pay a series attention the relationship between the subsectors of export such as agriculture export and economic growth. For developing countries whereas, agriculture is main source of income and their export plays key in economic growth (BERKUM \& MEIJL, 2000; TAHAR, 2014). Balanced growth can be accelerate through agriculture trade in all countries if there no issue of trade restriction and bounds in the world (ANDERSON \& MARTIN, 2005; LABORDE \& MARTIN, 2013). Through nonlinear and linear granger causality test it is revealed that there is causal relationship between export and economic growth (AJMI, et al., 2015). While the study of (LI, et al., 2010) test con-integration analysis of import and export relationship with economic growth and the outcome suggests that import has significant and export insignificant effect on economic growth. It is expressed the relationship between agriculture export and Gross domestic product has positive effect for long time in Pakistan economy (CURRY \& HENNEBERRY, 1992) and the results showed the existence of long term relationship. (KANG, 2015) examines the evidence of the export-led growth in major rice exporting countries using some econometric approaches. The results check that agricultural export- led growth in the major rice exporting countries such as Pakistan, Vietnam and Thailand. In the same direction (DAWSON, 2015) examines the involvement of agricultural exports to economic growth in less developed countries. The results show significant structural differences in economic growth between low, lower-middle, and upper-income countries. The findings further indicate that investment in the agricultural export has an effect on economic growth in those countries. Similarly, some studies (BIEKPE \& OCRAN, 2008; OMOTOR, et al., 2010; OJO, et al., 2014) have also checked the hypothesis that agricultural export-led economic growth in Nigeria.

The import- led growth hypothesis suggests that economic growth could be driven primarily by growth of imports (TODA et al, 1995). Latest endogenous growth models have stressed the significance of imports as an important channel for 
international technology and information to flow into the local economy (NADEEM, 2010). The innovative technology may perhaps be seen as embodied in imports of intermediate goods such as machines and labour performance could increase over time as workers gain the information to unbundle the new embodied technology (THANGAVELU, 2004). Some studies that have been conducted elsewhere are of the opinion that there is a unidirectional causality running from imports to economic growth while in some cases it runs from economic growth to imports. Other empirical studies support bidirectional causality where there is both import-led growth and growth- led imports existing at a time in an economy. However, there are also some who argue that there is no causality in any direction between economic growth and imports. The precise role of imports on economic growth tactics mainly via technology allocation and spillovers; new industry impact encouraged by consumption and competition impact as well as import impact on export promotion (FUCHSLOCHER, 2007). It is confirmed through bound test that import has impact on Pakistan economy for long term (AFZAL, et al., 2010).

Exchange rate stability is pivotal to the achievement of macroeconomic stability and the economic performance of any country in the global economy. Thus, exchange rate policy plays a significant role in determining an appropriate exchange rate and ensuring its stability. Exchange rate refers to the rate at which one currency is exchanged for another (INAM \& UMOBONG, 2015). It is the duty of State bank of Pakistan to carrying out exchange rate and monetary policies. The purpose of monetary policies is to keeping exchange rate stability whereas to promote economic growth. It is investigated that there is causality from exchange rate towards economic growth for the nine European countries (KARAMELIKLI \& KORKMAZ, 2016). Exchange rates impressively influence cross-border economic business, according to (FRIEDEN, et al. 2010). The exchange rate regime has positive impact on economic growth (AIZENMAN, 1994). The granger casualty test checked the occurrence of bidirectional causal relation between economic growth, trade openness and exchange rate in Pakistan economy (RAZA \& AFSHAN, 2017). Several scholars revealed exchange rates cause to its global importance and influence on the economic stability, performance, trade arrangements and investments (JONGWANICH, 2008, BERG \& MIAO, 2010).

This study investigated the Pakistan economic growth with exchange currency value which is consistently depreciated for long time it was also showed that the GDP position is declining for four decade (FAO, 2016, FAO, 2017). Exchange rate is a macroeconomic factor which is influencing the foreign direct investment, foreign trade, unemployment, inflation and gross domestic product (BAHMANI \& JIA, 2012). Important position of agriculture sector in our economy whereas the study accepted that exchange rate is macroeconomic factor which effect the agricultural trade (MUSTAFA, et al., 2004). For the high international trade, price stability and suitable monetary policy the exchange rate regime are very important factors (FRIEDEN, et al., 2010). If there is positive links between exchange rate and gross domestic product, then stable exchange rate could lift the economic growth (COUDERT \& DUBERT, 2004; ARRATIBEL, et al., 2011; DANMOLA, 2013). Strong linkages between agricultural export import products and exchange rate with economic growth and these macroeconomic factors also have relationship with each other which directly and indirectly which effects economic growth of Pakistan. Furthermore the agriculture import of capital good play key role for the domestic production, agriculture export can be pushed through agriculture import new technology adaptation and best policy and also moderate exchange rate alternately can bring a positive influence on economic development.

Agriculture sector is much more important in economic development of our country (IQBAL, et al., 2003), it is very essential to find out the short run, long run relationship as well as causality test with external factors agriculture such as agriculture import, agriculture export and exchange rate with country GDP which could be helpful for country finance department, agriculture department and policy perspectives. The country economists should consider for smooth and reliable economic growth and its linkage with external variables for significant result, this policy and strategies is not only applicable in case of Pakistan but also for other economically developing countries.

The rest of the article is arranged as follow: In section 2 the theoretical background indicates the time series graph trend. Section 3 interprets the conceptual framework which shows the direction of research. Section 4 comprises of method and data set used. The motive we choose to study Pakistan and its essential agriculture trade relationship with economic growth will be analysis in this part. Section 5 , presents the result and discussion of this paper. While the last section represents the conclusion and recommendation on the basis of results. 


\section{MATERIALS AND METHODS}

\section{Theoritcal Background}

The relationship between exports and economic growth has been attributed to the potential positive externalities derived from exposure to foreign markets. More specifically, exports can be viewed as an engine of growth in three ways. First, export expansion can be a catalyst for output growth directly as a component of aggregate output. An increase in foreign demand for domestic exportable products can cause an overall growth in output via an increase in employment and income in the exportable sector. Second, export growth can also affect growth indirectly through various routes such as: efficient resource allocation, greater capacity utilization, exploitation of economies of scale and stimulation of technological improvement due to foreign market competition (EATON, 1986). expanded imports have the potential to play a complementary role in stimulating overall economic performance. It is plausible to assume that the effect of imports on economic growth may be different from that of exports. For instance, in many small open developing economies, imports provide much needed factors of production employed in the export sector. Also, the transfer of technology from developed to developing countries via imports could serve as an important source of economic growth. Endogenous growth models show that imports can be a channel for longrun economic growth because it provides domestic firms access to foreign technology and knowledge (COE \& HELPMAN, 1993). In a sense, imports as a medium of technology transfer may play a more significant role on economic growth than exports (HYE, 2012).

Currently monetary policy has been driven by efforts to maintain the stable exchange rate and buildup foreign exchange reserves (SVENSSON, 2018). The promotion of economic growth is possible due to the good and stable monetary policy. Exchange rate system is very important factor for economic growth of country (RODRIK, 2008). The country currency value compared with other currency value is known as exchange rate (KRUGMAN, 2001). Exchange rate is divided into two categories such as fixed and flexible exchange rate (RAJAN, 2012). The governing body is set out the fixed rate while flexible rate is set out by market without any pressure of the government in the effort to stabilize the money circulation. It is documented that the high economic growth rate revealed adequate export growth, while exchange rate value appreciated due to high demand for country currency (NURINA, 2016). Stable exchange rate is maintaining the liquidity of capital markets and to peruse the investors which is turn out to attain the desirable economic growth (WONG, et al., 2005).

Figure 1 which shows yearly dynamic movements of agriculture export and import from 1980 to 2017 of the time series data used in study. The data was taken from World trade organization and food agriculture organization. However the agricultural export and agricultural import is presented in million US\$. From 1980 to 1990 the agriculture trade showed deficit because agriculture import is greater than export. In years 1991 astonishing performance the total agriculture export and import products volume are US\$1236 and 1353 million respectively in US dollar at this point the exchange rate was also stable of our country. Onward the agriculture trade volume was in deficit from 2000 to 2010 the economic growth is very slow because of exchange rate of Pakistani rupee (PKR) value was depreciated due to political instability and the government of Pakistan did not pay to too much attention to agriculture sector development. During the year 2011 the agriculture trade was in surplus afterward the agriculture trade once again showed deficit line till 2017. Four decades trend line is demonstrated that the volume of agricultural import and export products thoroughly dominant by import and also average trade deficit till to 2017 .

The figure 1 shows the relationship between exchange rate and GDP, it shows that the exchange rate was stable from 1980 to 1990 and GDP was moving upward it show the economic growth while it revealed these fixed exchange rate have positive relationship with annual growth. However from 1991 to 2000 time series data shows that annual economic growth is declining and exchange rate value is depreciated as result of the country economic development was declining. It is clearly identified that the last three decade for the economy was not good because the value of exchange rate is depreciated and annual growth rate not increased. However the economist need to revised and make strong and sustainable policy in regards to exchange rate for the better national economy and economic growth productivity.

\section{Models and methods \\ Model specifications}

Some hidden and unexpected events, such as financial and economic crises, revolutions, and political changes, which can lead the deficiency of linear approaches to capture the relationship 


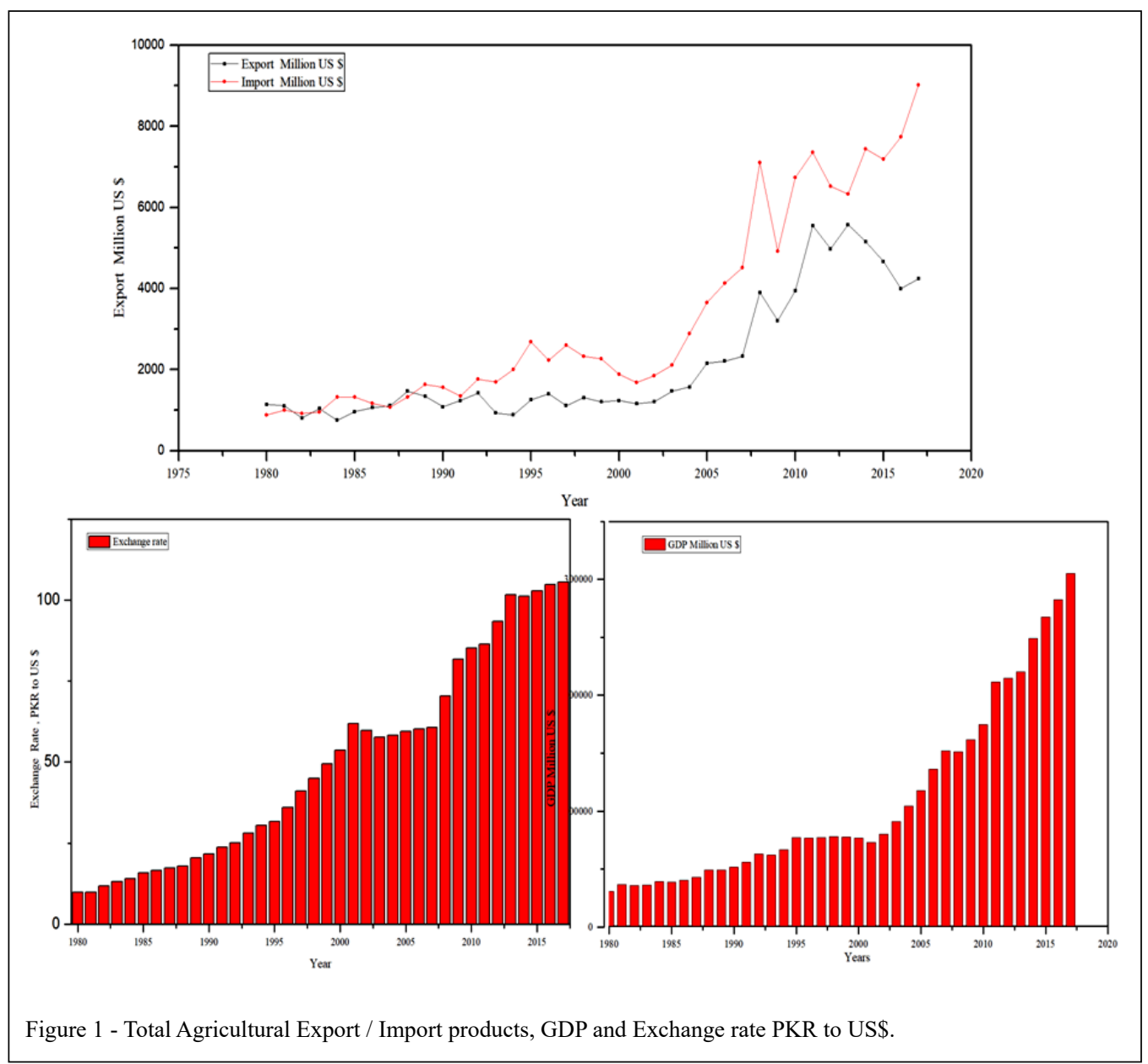

among the economic time series data. To capture the nonlinear and asymmetric co-integration between the variables, we employed the multivariate NARDL model, which also distinguishes between long-run and short-run effects of the independent variables on dependent variables. Furthermore, this is a suitable instrument for time series data to test co-integration among the variables in a single equation (SHIN, Y et al. 2014). Additionally, other Co-integration models support only integrated order at either 1 or I (1) for all variables, whereas the NARDL test permits integrated orders of either $\mathrm{I}(0)$, I(1) or a combination of both. Here, the Vector Error Correction Model can be used, but it has a convergence problem due to the large number of parameters and, with same integration order of the time series, the NARDL model is free from the integration order restriction shown by (YEAP \& LEAN, 2017).

$\Delta Y_{t}=\alpha_{0}+\rho Y_{t-1}+\phi_{1}^{+} E_{t-1}^{+}+\phi_{2}^{-} E_{t-1}^{-}+\phi_{3}^{+} I_{t-1}^{+}+\phi_{4}^{-} I_{t-1}^{-}+\phi_{5}^{+} X_{t-1}^{+}+\phi_{6}^{-} X_{t-1}^{-}+$

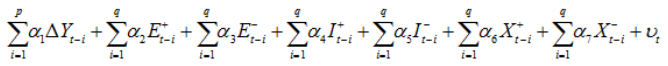

In Eq. $1, \alpha_{i}$ and $\phi_{i}$ represent coefficient of short run and long run respectively with $i=1 \ldots . .8$. Here, short-run coefficients reveal the immediate effect of independent variables on dependent variables. On the other hand, long-run coefficients show the speed and reaction time of the adjustment towards an equilibrium level. By employing the Wald test to analyses the null hypothesis for short-run asymmetry is $\phi=\phi^{+}=\phi^{-}$and $\alpha=\alpha^{+}=\alpha^{-}$for short run for variables, $Y_{t}$ economic growth, $E_{t}$ agricultural exports, $I_{t}$ agricultural imports and $X_{t}$ exchange rate. Where $\mathrm{p}$ and $\mathrm{q}$ represent optimal lags and $t$ indicates time.

To decomposed all exogenous variables into negative and positive partial sum as follow by employing causality test to capture asymmetric causal relationship among the variables by considering 
negative and positive shocks. The integrated variables can be represented as below:

It can also express as below:

$Y_{1 t}=Y_{1 t-1}+\varepsilon_{1 t}=Y_{10}+\sum_{i=1}^{t} \varepsilon_{1 i}$ and $Y_{2 t}=Y_{2 t-1}+\varepsilon_{2 t}=Y_{20}+\sum_{i=1}^{t} \varepsilon_{2 i}$

Where $\mathrm{t}=1,2 \ldots . \mathrm{T}, Y_{1 t}$ and $Y_{2 t}$ represents the initial values, and error terms denoted by $\varepsilon_{1 t}$ and $\varepsilon_{2 t}$. By taking positive and negative shocks are sho wn: $\varepsilon_{1 i}^{+}=\max \left(\varepsilon_{1 i}, 0\right)$ and $\varepsilon_{2 i}^{+}=\max \left(\varepsilon_{2 i}, 0\right) \quad$ indicates positive shocks. Where $\varepsilon_{1 i}^{-}=\min \left(\varepsilon_{1 i}, 0\right)$ and $\varepsilon_{2 i}^{-}=\min \left(\varepsilon_{2 i}, 0\right)$ represent the negative shocks.

\section{Asymmetric causality tests}

The asymmetric causality test, recently adopted by (HATEMI-J, 2012) is used to determine the direction of the asymmetric causal relationship between the variables. The main reason for employing the (TODA, et al., 1995) test is to check nonlinear effects and to discriminate between positive and negative shocks. (HATEMI-J, 2012) J showed that the variables can be a random walk process, in the below form:

$$
\begin{aligned}
& Y_{1 t}=Y_{1 t-1}+\varepsilon_{1 t}=Y_{1,0}+\sum_{i=1}^{t} \varepsilon_{1 i}^{+}+\sum_{i=1}^{t} \varepsilon_{1 i}^{-} \text {And similarly } \\
& Y_{2 t}=Y_{2 t-1}+\varepsilon_{2 t}=Y_{2,0}+\sum_{i=1}^{t} \varepsilon_{2 i}^{+}+\sum_{i=1}^{t} \varepsilon_{2 i}^{-}
\end{aligned}
$$

The positive and negative shocks of the variables can be expressed in cumulative form are given below:

$$
\begin{gathered}
Y_{t}^{+}=\sum_{i=1}^{t} \varepsilon_{1 i}^{+}, Y_{t}^{-}=\sum_{i=1}^{t} \varepsilon_{1 t}^{-}, E x p_{2}^{+}=\sum_{i=1}^{t} \varepsilon_{2 i}^{+}, E x p_{2}^{-}=\sum_{i=1}^{t} \varepsilon_{2 i}^{-}, \operatorname{Im} p_{t}^{+}= \\
\sum_{i=1}^{t} \varepsilon_{3 i}^{+}, \operatorname{Im} p_{t}^{-}=\sum_{i=1}^{t} \varepsilon_{3 i}^{-}, E x_{t}^{+}=\sum_{i=1}^{t} \varepsilon_{4 i}^{+}, E x_{t}^{-}=\sum_{i=1}^{t} \varepsilon_{4 i}^{-}
\end{gathered}
$$

To test the causality among the variables by employing the vector autoregressive (VAR) model by selecting order $\mathrm{p}$, for this purpose the following criterion is used to select optimal lag $\mathrm{p}$ :

$\mathrm{HJC}=\left|\hat{A}_{j}\right|+J\left(\frac{n^{2} \ln T+2 n^{2} \ln (\ln T)}{2 T}\right)$

The symbols used in the equation are described below:

$$
\mathrm{J}=0 \ldots \mathrm{p} \text {. Where }\left|\hat{A}_{j}\right| \text { represents the }
$$
determinant of the estimated |variance-covariance matrix of the error terms in the VAR model with using lag order $\mathrm{q}$ and number of equations, and $\mathrm{n}$ represent the number of variable that are used in the VAR model, and ' $T$ ' shows the number of observation (sample size). Where the null hypothesis up to $K^{\text {th }}$ element of $Y_{t}^{+}$which does not cause $w^{\text {th }}$ element of the $Y_{t}^{+}$(Figure 2).

\section{Hypothesis} which are;
Ho There are no granger causalities of agriculture export product on gross domestic product.

H1 There are granger causalities of agriculture export product gross domestic product.

Ho There are no granger causalities of agriculture import product on gross domestic product.

H1 There is influence of agriculture import product on gross domestic product.

Ho There are no granger causalities of exchange rate on gross domestic product.

H1 There are granger causalities of exchange rate on gross domestic product.

\section{RESULTS AND DISCUSSION}

In this step table 1 and 2, we ensure to know that all variables to be stationary and none of them would be integrated at I(2). By employing Augmented Dickey Fuller (ADF)(DICKEY; FULLER, 1979) and Phillips-Perron (PP) to get that economic growth has unit root at $\mathrm{I}(0)$ with intercept and trend but it's found stationary at $1^{\text {st }}$ difference and others variables agriculture exports, agriculture imports and exchange rate are stationary at both level and $1^{\text {st }}$ difference. Moreover, the structural break point also calculated by employing ADF structural break test (Table 2A). Table 3 shows that are 0.9070 and 0.8141 respectively, which means that agriculture exports, agriculture imports and exchange rate explain $90.70 \%$ of economic growth. The from (SHIN, et al. 2014) suggest the reliability and validity of model at $1 \%$ significant level. The t-statistic adopted by (BANERJEE, et al. 1998) confirms the co-integration among the variables at $1 \%$ significant level. The t-statistic confirm the absence of White heteroscedasticity $\left(\chi_{H E T}^{2}\right)$ and serial correlation $\left(\chi_{s c}^{2}\right)$ issue in model. Furthermore, the Durbin Watson (DW) test also confirm the absence of autocorrelation in the model.

Table 4 shows nonlinear autoregressive distributed lag (NARDL) model adopted by (SHIN, et al., 2014) to investigate long-run and short-run cointegration among the variables, economic growth, agriculture exports, imports and exchange rate. For this aspect all variables are decompose into negative and positive manners. All short-run and long-run relationship are reported in table 4.

\section{In the long term results}

A positive shocks to agriculture imports has positive long-run effect on economic growth at $1 \%$ significant level with coefficient $(0.2011)$, while a negative shocks to imports also has positive influence on economic growth with coefficient $(0.3474)$ at $5 \%$ 


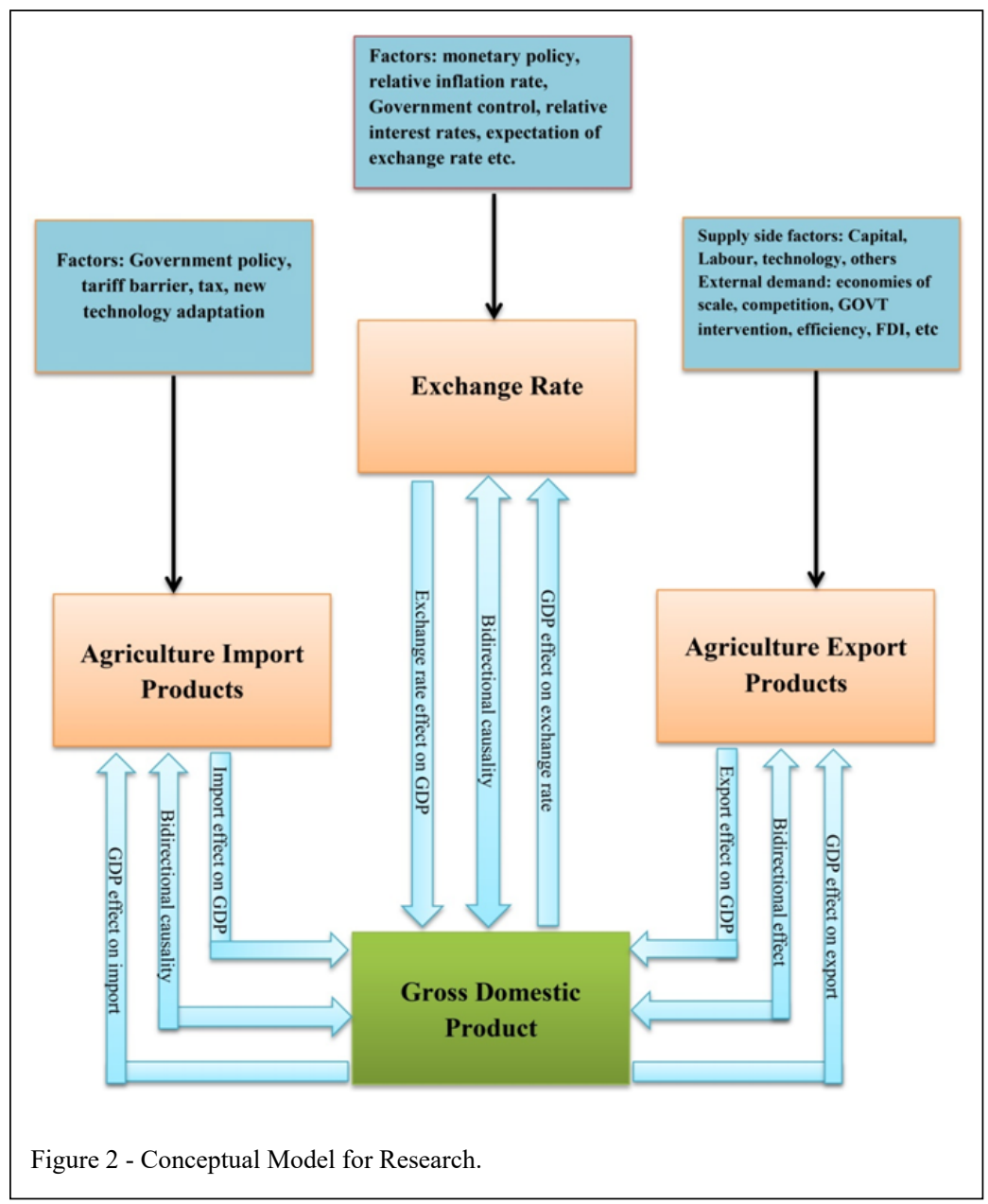

significant. We assumed that decrease or increase in imports will affect the economic growth the results in line with (SECK, 2012). In long-run, a positive shocks to agriculture exports will positive affect on economic growth with (coefficient 0.1310 ) means that strong positive relationship noted between the variables the study is in line with (AKHTER, 2015). The negative sign of exports coefficient has negative relationship with economic, which shows that a $1 \%$ increase or decrease in agriculture exports will drop down economic growth with coefficient $(0.1310$ and -0.0799 ) respectively and the agriculture export

Table 1 - Unit Root Test Results

\begin{tabular}{|c|c|c|c|c|}
\hline \multirow[t]{2}{*}{ Variables } & \multicolumn{4}{|c|}{ 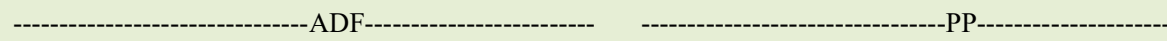 } \\
\hline & Level & $1^{\text {st }}$ Difference & Level & $1^{\text {st }}$ Difference \\
\hline$Y_{t}$ & -2.1139 & $-9.1011^{* * *}$ & -2.3303 & $-8.1759^{* * *}$ \\
\hline$I_{t}$ & $-4.6114^{* * *}$ & $-8.4713^{* * *}$ & $-4.6420^{* * *}$ & $-9.0486^{* * *}$ \\
\hline$E_{t}$ & $-4.7579^{* * *}$ & $-8.8804^{* * *}$ & $-4.9103^{* * *}$ & $-12.4683^{* * *}$ \\
\hline$X_{t}$ & $-3.2281^{*}$ & $-9.2433^{* * *}$ & $-3.7640^{* *}$ & $-8.5641^{* * *}$ \\
\hline
\end{tabular}

Note: Coefficient significant ${ }^{*},{ }^{* *}$, and ${ }^{* * *}$ are indicated by $10 \%, 5 \%$ and $1 \%$. 
Table 2 - Diagnostic Statistics Results.

\begin{tabular}{lccc}
\hline Test & Results & Test & Results \\
\hline $\mathrm{L}_{\mathrm{I}}^{+}$ & 0.4371 & $\mathrm{~L}_{1}^{-}$ & -0.7514 \\
$\mathrm{~L}_{\mathrm{E}}^{+}$ & -0.0393 & $\mathrm{~L}_{\mathrm{E}}^{+}$ & -0.2021 \\
$\mathrm{~L}_{\mathrm{X}}^{+}$ & -1.1329 & $\mathrm{~L}_{\mathrm{X}}^{-}$ & -10.5207 \\
$\mathrm{~W}_{\text {I.R.E }}^{-}$ & $\mathrm{W}_{\text {S.R.I }}$ & $5.8589^{* * *}$ \\
$\mathrm{~W}_{\text {I.R.E }}$ & $4.9253^{* *}$ & $\mathrm{~W}_{\text {S.R.E }}$ & $2^{*}$ \\
$\mathrm{~W}_{\text {I.R.X }}$ & 0.1298 & $\mathrm{~W}_{\text {S.R.X }}$ & $1.3653^{*}$ \\
$\mathrm{R}^{2}$ & $7.3838^{* * *}$ & $\mathrm{ADJ}^{2}$ & $19.3038^{* * *}$ \\
$\mathrm{X}_{\text {HET }}^{2}$ & 0.9562 & $\mathrm{D}^{2} \mathrm{~W}$ & 0.8945 \\
$\mathrm{~F}_{\text {PSS }}$ & $35.3575[0.0633]$ & $\mathrm{T}_{\mathrm{BDM}}$ & 2.6985 \\
\hline
\end{tabular}

Note: + And - represents positive and negative, while L shows long-run coefficient. $\mathrm{W}_{\mathrm{I} . \mathrm{R}}$ and $\mathrm{W}_{\mathrm{S} . \mathrm{R}}$ indicate long-run and short-run Wald test. Coefficient significant ${ }^{*},{ }^{* *}$, and ${ }^{* * *}$ are indicated by $10 \%, 5 \%$ and $1 \%$.

Côte d'Ivoire and Nigeria has negative impact on economic growth (RICHARDSON et al., 2016). In long term, positive shocks to exchange rate has inverse relationship with economic growth study is in line with (RAZA \& AFSHAN, 2017). An increase in exchange rate has positive impact on the economy. A negative shocks to exchange has strongly effect the economic growth with coefficient (-1.0204) insignificant for Economic growth. Several studies indicated the exchange rate negative impact on economic growth (JAKOB, 2015).

\section{In the short term results}

In short term, the positive shocks of agriculture imports has positive impact on economic growth at lag 0 (with coefficient 0.1841 ) the study is in line with (ABDULL, 2015). On at vary short run of negative shocks in imports on (lag 0 , coefficient at lag $1,-0.3748$ and lag $2,-0.1883$ ) have negative impact on economic growth with $1 \%$ significant level. A positive shocks in export at (lag 2) have inverse relationship with economic growth (coefficient -0.1672). Another nexus noted between negative shocks to agriculture exports and economic growth at lag 0 (coefficient 0.1156). The outcome indicated that agriculture trade has negative influence because the country import has greater than export (ANOWOR et al., 2013). While negative shocks in agriculture exports at (lag 2) have negative impact on economic growth (coefficient 0.1757). In vary short run (lag 0 ) of positive shocks to exchange rate has inverse relationship with economic growth at $1 \%$ significant but at (lag 2) have positive impact on Pakistan economy insignificant. The positive effect of exchange rate on economic growth in Nigeria (VERTER, 2016).
In most of empirical studies, VECM Granger causality test one of the popular techniques in nowadays to identify the nexus among the variables. However, there are some major drawbacks in VECM Granger causality in terms of positive and negative shocks in economy which are not taken into account. These shocks play a vital role for trading purpose in the events of good or bad news. Therefore, in our study asymmetric causality adopted and applied to investigate asymmetric relationship among positive and negative shocks of the variables.

Table 5 shows asymmetric causality among the variables, economic growth, agriculture exports, agriculture imports and exchange rate to capture the causal nexus between positive and negative shocks. Line 1 reveals the symmetric causal nexus between agriculture export and economic growth. An asymmetric causal relationship found between positive shocks in export to positive shocks economic growth in (line 2) while null hypothesis is rejected. The outcome is relate to the study of (SHIRAZI \& MANAP, 2005; SHOMBE, 2008; BBAALE \& MUTENYO, 2011; OJIDE, et al., 2014; OJO, et al., 2014) who identified that agricultural export have positive relationship with economic growth in Nigeria and other states. The export and economic growth ganger causality result shows unidirectional effect on each other. Furthermore, negative shocks in agriculture export does not affect the negative shocks in economic growth in (line 3). In (line 5) positive shocks in economic growth and agriculture exports has reject the null hypothesis of causal nexus, moreover the negative shocks to economic growth not affect export in (line 6) from economic growth to agriculture exports. These outcomes shows that either 
The impact of agriculture trade and exchange rate on economic growth of Pakistan: an NARDL and asymmetric analysis approach. 9

Table 3 - Non-linear Autoregressive distributed lag test result.

\begin{tabular}{|c|c|c|}
\hline Variables & Coefficient & Probability \\
\hline Constant & $1.27846^{*}$ & 0.0745 \\
\hline$Y_{t-1}$ & $-0.1400^{*}$ & 0.0683 \\
\hline$I_{t-1}^{+}$ & $0.0612^{*}$ & 0.0604 \\
\hline$I_{t-1}^{-}$ & $-0.1052^{* *}$ & 0.0521 \\
\hline$E_{t-1}^{+}$ & -0.0055 & 0.9386 \\
\hline$E_{t-1}^{-}$ & -0.0284 & 0.6494 \\
\hline$X_{t-1}^{+}$ & -0.1586 & 0.1790 \\
\hline$X_{t-1}^{-}$ & $-1.4729^{* * *}$ & 0.0026 \\
\hline$\Delta Y_{t-1}$ & -0.1608 & 0.1748 \\
\hline$\Delta Y_{t-2}$ & $0.3995^{* *}$ & 0.0181 \\
\hline$\Delta Y_{t-3}$ & $0.3651^{* *}$ & 0.0170 \\
\hline$\Delta I_{t}^{+}$ & 0.0721 & 0.1024 \\
\hline$\Delta I_{t}^{-}$ & $-0.1421^{* * *}$ & 0.0081 \\
\hline$\Delta I_{t-1}^{-}$ & $-0.1506^{* * *}$ & 0.0014 \\
\hline$\Delta I_{t-2}^{-}$ & $-0.1090^{* *}$ & 0.0206 \\
\hline$\Delta E_{t}^{+}$ & $-0.0862^{*}$ & 0.0740 \\
\hline$\Delta E_{t-1}^{+}$ & $-0.1377^{* *}$ & 0.0180 \\
\hline$\Delta E_{t-2}^{+}$ & $-0.0867^{* *}$ & 0.0374 \\
\hline$\Delta E_{t}^{-}$ & 0.0795 & 0.1704 \\
\hline$\Delta E_{t-2}^{-}$ & $-0.0995^{* *}$ & 0.0486 \\
\hline$\Delta E_{t-3}^{-}$ & $-0.0881^{*}$ & 0.0672 \\
\hline$\Delta X_{t}^{+}$ & $-0.9893^{* * *}$ & 0.0000 \\
\hline$\Delta X_{t-2}^{+}$ & $0.4982^{* *}$ & 0.0171 \\
\hline$\Delta X_{t-3}^{+}$ & $0.7634^{* * *}$ & 0.0016 \\
\hline
\end{tabular}

Note: Coefficient significant ${ }^{*},{ }^{* *}$, and ${ }^{* * *}$ are indicated by $10 \%, 5 \%$ and $1 \%$.

Table 4 - Asymmetric and symmetric causality Results.

\begin{tabular}{|c|c|c|c|}
\hline No & Causalities & Values & Probabilities \\
\hline 1. & $E_{t} \Rightarrow Y_{t}$ & $41.2131^{* * *}$ & 0.0000 \\
\hline 2. & $E_{t}^{+} \Rightarrow Y_{t}^{+}$ & $26.0084^{* * *}$ & 0.0010 \\
\hline 3. & $E_{t}^{-} \Rightarrow Y_{t}^{-}$ & $34.3197^{* * *}$ & 0.0000 \\
\hline 4. & $Y_{t} \nRightarrow E_{t}$ & 70.1372 & 0.5219 \\
\hline 5. & $Y_{t}^{+} \Rightarrow E_{t}^{+}$ & $13.8195^{*}$ & 0.0866 \\
\hline 6. & $Y_{t}^{-} \nRightarrow E_{t}^{-}$ & 9.5311 & 0.2995 \\
\hline 7. & $I_{t} \nRightarrow Y_{t}$ & 7.2552 & 0.5094 \\
\hline 8. & $I_{t}^{+} \Rightarrow Y_{t}^{+}$ & $19.1181^{* *}$ & 0.0142 \\
\hline 9. & $I_{t}^{-} \Rightarrow Y_{t}^{-}$ & $13.5922^{*}$ & 0.0930 \\
\hline 10. & $Y_{t} \nRightarrow I_{t}$ & 8.7441 & 0.3636 \\
\hline 11. & $Y_{t}^{+} \nRightarrow I_{t}^{+}$ & 7.0651 & 0.5296 \\
\hline 12. & $Y_{t}^{-} \Rightarrow I_{t}^{-}$ & $26.5906^{* * *}$ & 0.0008 \\
\hline 13. & $X_{t} \Rightarrow Y_{t}$ & $20.0018^{* *}$ & 0.0103 \\
\hline 14. & $X_{t}^{+} \Rightarrow Y_{t}^{+}$ & $20.3262^{* * *}$ & 0.0092 \\
\hline 15. & $X_{t}^{-} \Rightarrow Y_{t}^{-}$ & $14.2360^{*}$ & 0.0758 \\
\hline 16. & $Y_{t} \Rightarrow X_{t}$ & $29.4081^{* * *}$ & 0.0003 \\
\hline 17. & $Y_{t}^{+} \nRightarrow X_{t}^{+}$ & 5.0559 & 0.7516 \\
\hline
\end{tabular}

Note: Coefficient significant ${ }^{*},{ }^{* *}$ and ${ }^{* * *}$ are indicated by $10 \%, 5 \%$ and $1 \% \nRightarrow / \Rightarrow$ show number of causality / unidirectional causality.

Ciência Rural, v.50, n.4, 2020. 
Table 5 - Asymmetric and symmetric causality.

\begin{tabular}{|c|c|c|c|c|c|}
\hline No & Causalities & Values & CV $1 \%$ & CV 5\% & CV $10 \%$ \\
\hline 1 & $E_{t} \Rightarrow Y_{t}$ & $5.925 * *$ & 8.455 & 4.425 & 3.104 \\
\hline 2 & $E_{t} \Rightarrow Y_{t}$ & $7.885^{*}$ & 13.771 & 13.771 & 6.609 \\
\hline 3 & $E_{t}^{-} \Rightarrow Y_{t}^{-}$ & 0.323 & 13.061 & 7.639 & 5.599 \\
\hline 4 & $Y_{t} \nRightarrow E_{t}$ & 0.393 & 10.684 & 6.856 & 5.116 \\
\hline 5 & $Y_{t}^{+} \Rightarrow E_{t}^{+}$ & 0.506 & 12.729 & 7.608 & 5.794 \\
\hline 6 & $Y_{t}^{-} \nRightarrow E_{t}^{-}$ & 6.095 & 20.371 & 11.707 & 8.871 \\
\hline 7 & $I_{t} \nRightarrow Y_{t}$ & $13.324^{* *}$ & 17.958 & 11.933 & 9.094 \\
\hline 8 & $I_{t}^{+} \Rightarrow Y_{t}^{+}$ & $7.005^{*}$ & 14.260 & 9.056 & 6.872 \\
\hline 9 & $I_{t}^{-} \Rightarrow Y_{t}^{-}$ & 0.011 & 14.022 & 7.700 & 5.390 \\
\hline 10 & $Y_{t} \nRightarrow I_{t}$ & 1.870 & 10.895 & 6.745 & 5.038 \\
\hline 11 & $Y_{t}^{+} \nRightarrow I_{t}^{+}$ & 0.462 & 12.484 & 7.579 & 5.784 \\
\hline 12 & $Y_{t}^{-} \Rightarrow I_{t}^{-}$ & 4.591 & 22.612 & 11.926 & 8.710 \\
\hline 13 & $X_{t} \Rightarrow Y_{t}$ & 3.928 & 12.545 & 8.069 & 6.119 \\
\hline 14 & $X_{t}^{+} \Rightarrow Y_{t}^{+}$ & 1.091 & 14.752 & 9.208 & 7.070 \\
\hline 15 & $X_{t}^{-} \Rightarrow Y_{t}^{-}$ & $68.690^{* * *}$ & 26.585 & 13.430 & 10.004 \\
\hline 16 & $Y_{t} \Rightarrow X_{t}$ & 2.324 & 12.845 & 8.468 & 6.459 \\
\hline 17 & $Y_{t}^{+} \nRightarrow X_{t}^{+}$ & 2.334 & 14.489 & 9.539 & 7.404 \\
\hline 18 & $Y_{t}^{-} \Rightarrow X_{t}^{-}$ & 2.200 & 11.817 & 6.956 & 5.088 \\
\hline
\end{tabular}

Note: Coefficient significant ${ }^{*},{ }^{* *}$ and ${ }^{* * *}$ are indicated by $10 \%, 5 \%$ and $1 \% \nRightarrow / \Rightarrow$ shows no causality/unidirectional causality.

increase or decrease in agriculture exports will affect the economy. From these findings policy makers should focus on exports sector to ease their exporters. We find significant causality between agriculture imports and economic growth from imports to economic growth (line 7). In (line 8) positive shocks in imports effect on positive shocks in economic growth at $10 \%$ significant level. A neutral effect found in negative shocks to agriculture imports affect negative shocks in economic growth in (line 9). The neutral causality noted in negative shocks in economic growth and negative shocks agriculture imports running from economic growth to imports in (line 12). The bidirectional causality is rejected between import and economic growth while there is presence of unidirectional causality. While it is very hard to prove a negative relationship import and economic growth. We can take into consideration that there are different types of country import, if import is a consumption food, then it will be difficult to to boost up the economic growth; however, it the import is consist of technology, capital good and intermediate goods then it would be increase the overall economic activities. It is checked the relationship between economic growth and imported machines has positive and significant influence (MAZUMDAR, 2001).
Finally, we found neutral symmetric and asymmetric causal relationship between exchange rate and economic growth in (line 13 and 14). In (line 15) we note asymmetric causal relationship between negative shocks in exchange rate and positive shocks in economic growth at $1 \%$ significant level. Finally, the results confirm that neutral effect noted in both symmetric and asymmetric causality noted running from economic growth to exchange rate in (line 16-18). The symmetric causality result shows bidirectional effect as well in negative asymmetric causality has also bidirectional influence on each other. While subsequent studies reported that exchange rate regime have positive influence on economic growth (LEVY-YEYATI \& STURZENEGGER, 2003; SOKOLOV, et al., 2011; RAZA \& AFSHAN, 2017). The results of (MIRCHANDANI, 2013; BLEANEY, 1996) has logical sense that country production increase then currency demand increased and value is also appreciated against the foreign currency and ultimately affects the economic growth of country.

\section{Var stability of model}

CUSUM and CUSUM of square tests are used to check the stability of estimated model and the results are shown in figure 3 and 4 respectively. 


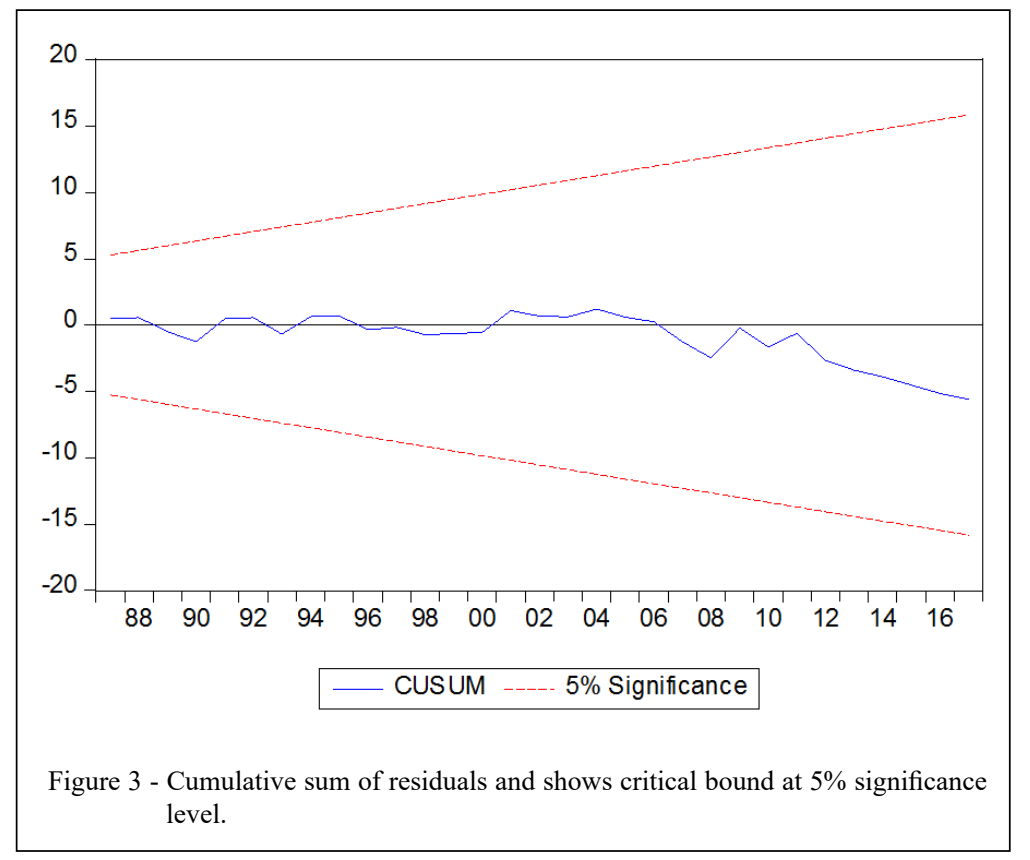

Figure 3 and 4 reveal the plot of is totally stable inside of 5\% critical band of VAR limit. The VAR is stationary fitted and stable for model.

\section{CONCLUSION AND RECOMMENDATION}

The objective of this study was to check the relationship between agriculture exports, imports products, exchange rate and economic growth of Pakistan in the annual period 1980-2017. The granger causality tests, cointegration test and NARDL model are applied to check the relationship between these variables. The nonlinear autoregressive model in the long has confirmed that the positive shocks of export and import with economic growth

A positive shocks to agriculture export has positive long-run effect on economic growth at $1 \%$ significant level, while a negative shocks to imports also has positive influence on economic growth with $5 \%$ significant while the exchange rate has positive relationship with economic growth. In short run the positive shocks in export and exchange rate have negative significant effect at $1 \%$ level with economic growth while the import positive has positive significant effect on economic growth at $1 \%$ level. The symmetric and non asymmetric granger results also investigated in our study between the variables. There is a unidirectional effect of agriculture export with economic growth in symmetrically. Import has no granger causality effect with while exchange rate has bidirectional effect with economic growth. While the asymmetric causality results has positive and negative shocks show in the study. Asymmetrically the positive shocks of export and economic growth has bidirectional effect while import and exchange rate have unidirectional causality with economic growth.

The agriculture export, import and economic growth have granger causality show in results while these results show the importance of export and import in gross domestic production of Pakistan. It can be argued that there is a basic requirement to boost export and investment agriculture sector to cover the value of import specifically in technological import product. Need to reduce on necessary agriculture import products because they effect the trade balance and economic growth planning new strategies and policies to develop agriculture trade. Need to enhance the share of gross fixed capital in agriculture sector. To seek new markets and bring innovation in manufacturing through advance improved technology and machinery. Government and private banks need to financing in agriculture sector.

The country economic variables such unemployment, inflation and monetary policy is effected by a foreign exchange rate. This study revealed that the exchange rate support the economic growth. The exchange rate value is maintaining economic 


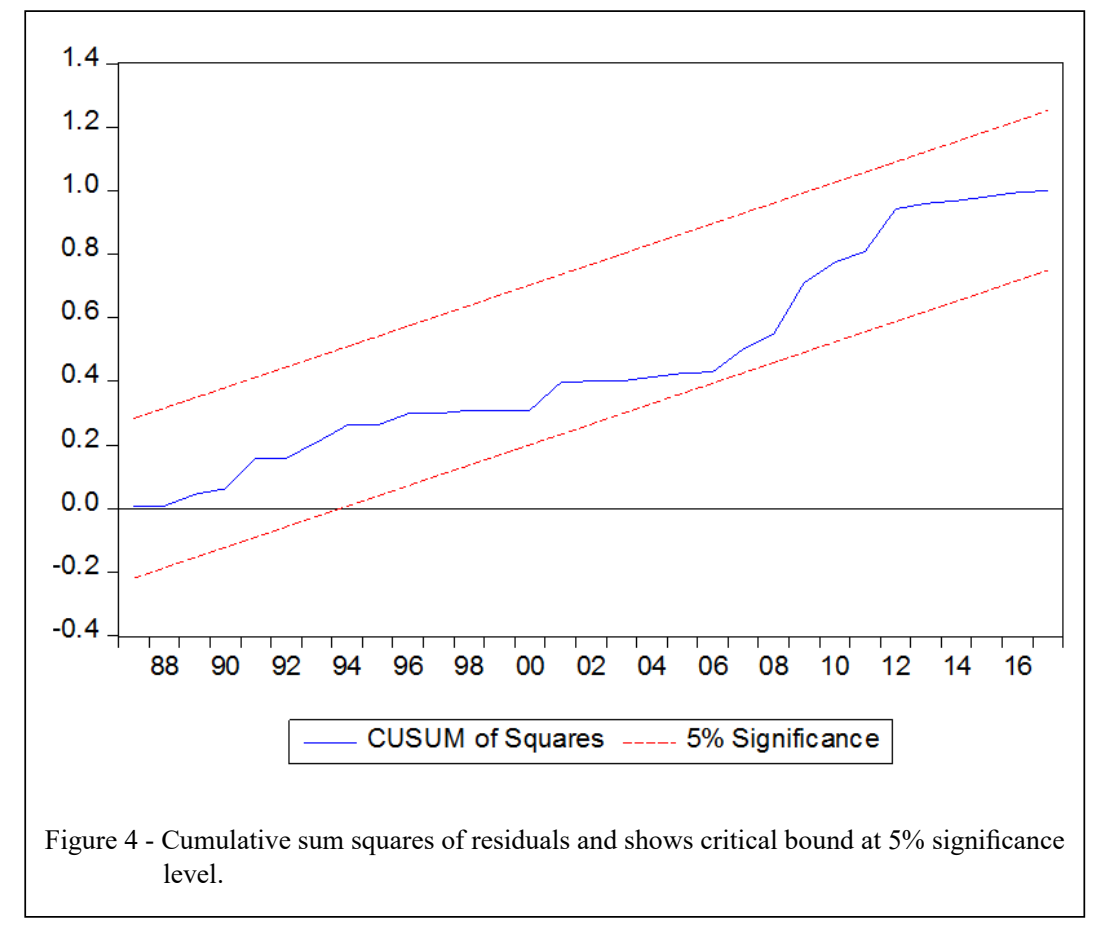

situation of country and support macroeconomic factors such as export, foreign direct investment, foreign reserve, investment and money supply in country which will turn to gain desired economic growth. Foreign trade and balance of payments can be affected through the fluctuation of real exchange rate so it is concluded that exchange rate is very important economic variables for economic growth. It is very important that the state bank of Pakistan should focus on real exchange rate policy and its governance.

\section{ACKNOWLEDGMENTS}

This research was sponsored by a major project supported by National Natural Social Science Foundation of China (No. 71573211)

\section{DECLARATION OF CONFLICT OF INTERESTS}

The authors declare no conflict of interest. The founding sponsors had no role in the design of the study; in the collection, analyses, or interpretation of data; in the writing of the manuscript, and in the decision to publish the results.

\section{AUTHORS' CONTRIBUTIONS}

IA and $\mathrm{XH}$ conceived and designed the research. $\mathrm{AK}$ and $\mathrm{KB}$ performed the data collection, analyzed the data and prepared the draft of the manuscript. HA, IK, QZ, and IA performed the proofread, edit, revised and approved the final version of manuscript collectively

\section{REFERENCES}

ABDULL, A. Impact of Exports and Imports on Economic Growth: Evidence from Tunisia, Journal of Emerging Trends in Economics and Management Sciences (JETEMS), 6(1):1321(2015). Available from: <https://jetems.scholarlinkresearch. com/>. Accessed: Dec. 15, 2018.

AFZAL, M., et al. Relationship between school education and economic growth in Pakistan: ARDL Bounds Testing Approach to Co-integration. Pakistan Economic \& Social Review, 48 (1): 39-60 (2010). Available from: <https://pdfs.semanticscholar. org/9651/.pdf>. Accessed: Dec. 12, 2018.

AIZENMAN, J. Monetary and Real Shocks, Productive Capacity and Exchange Rate Regimes. Economica, 61 (244): 4074349 (1994). Available from: <https://www.researchgate.net/ publication/4756113>. Accessed: Dec. 15, 2018.

AJMI, A. N. et al. Causality between exports and economic growth in South Africa: Evidence from linear and nonlinear tests. The Journal of developing areas, 49 (2): 163-181 (2015). Available from: <https://www.researchgate.net/publication/280064726>. Accessed: Dec. 12, 2018.

AKHTER, M. The Impact of Export and Import on Economic Growth in Bangladesh. 2015. Vol. 9 No. 1 Nov 2015, ISSN: 2078-8460 (2015). Available from: <https:// http://bv-f.org/WV09/06.\%20WV\%20Final.-9.pdf>. Accessed: Dec. 15, 2018. 
AKTER, M. N. B. Comparative Analysis Between Export-Led Growth and Import-Led Growth: A Study on Developing Eight (D-8). International Journal of Economics, Finance and Management Sciences. v.5, n.4, 2017, p.204-212, 2017. Available from: <https://www.researchgate.net/publication/320422457>. Accessed: Dec. 15, 2018.

ANDERSON, K.; MARTIN, W. J. Agricultural Trade Reform and the Doha Development Agenda. Journal of agriculture economics. 58(1). 2007. Available from: <https://www.researchgate.net/ publication/264465383>. Accessed: Dec. 15, 2018.

ANOWOR, O. F. et, al. The impact of trade liberalization on Nigeria agricultural sector. Journal of Economics and Sustainable Development. 4(8): 14-24 (2013). Available from: <https://www. researchgate.net/publication/309187845>. Accessed: Dec. 15, 2018.

ARRATIBEL, O. et al. The effect of nominal exchange rate volatility on real macroeconomic performance in the CEE countries. Economic Systems, 35(2): 261-277 (2011). Available from: $<$ https://www.researchgate.net/publication/227360549>. Accessed: Dec. 12, 2018.

BAHMANI, O. M.; JIA, X. Impact of exchange rate volatility on commodity trade between U.S. and China: is there a third country effect.Journal of Economics \& Finance, 36 (3): 555 586 (2012). Available from: <https://www.researchgate.net/ publication/246972810>. Accessed: Dec. 15, 2018.

BANERJEE, A., et al. Error correction mechanism tests for cointegration in a single equation framework. Journal of time series analysis, 19(3): 267-283 (1998). Available from: <https:/www. researchgate.net/publication/46431618>. Accessed: Dec. 15, 2018.

BBAALE, E.; MUTENYO, J. Export composition and economic growth in Sub-Saharan Africa: A panel analysis. The Journal of Sustainable Development, Vol. 6, Iss. 1 (2011), Pp. 1-19. Consilience (6): 1-19, 2011. Available from: <https://www. researchgate.net/publication/26600594>. Accessed: Dec. 15, 2018.

BERG, A.; MIAO, Y. The Real Exchange Rate and Growth Revisited: The Washington Consensus Strikes Back? Social Science Electronic Publishing, 10 (58): 1-24, 2010. Available from: <https://www.researchgate.net/publication/228259445>. Accessed: Dec. 15, 2018.

BERKUM, S. V.; MEIJL, H. V. The application of trade and growth theories to agriculture: a survey. Australian Journal of Agricultural \& Resource Economics, 44(4): 505-542, 2000. Available from: <https://www.researchgate.net/ publication/227364939>. Accessed: Dec. 15, 2018.

BIEKPE, N.; OCRAN, M. K. Primary commodity export and economic growth in sub-Sahara Africa: evidence from panel data analysis: economics. South African Journal of Economic \& Management Sciences, 11(4): 465-474, 2008. Available from: $\quad<$ https://www.researchgate.net/publication/289192439>. Accessed: Dec. 15, 2018.

BLEANEY, M. Macroeconomic stability, investment and growth in developing countries. Journal of Development Economics, 48(2), 461-477, 1996. Available from: < https://www.researchgate. net/publication/22216182>. Accessed: Dec. 15, 2018.

BOLTHO, A. Was Japanese growth export-led? Oxford Economic Papers, 48(3): 415-432, 1996. Available from: <https://www. researchgate.net/publication/5215463>. Accessed: Dec. 12, 2018. COE, D. T.; HELPMAN, E. International R \& D spillovers. European Economic Review, 39(5): 859-887, 1993. Available from: <https://www.researchgate.net/publication/4847206>. Accessed: Dec. 15, 2018.

COUDERT, V.; DUBERT, M. Does exchange rate regime explain differences in economic results for Asian countries? Working Papers, 16(5): 874-895, 2004. Available from: $<$ https://www.researchgate.net/publication/222424855>. Accessed: Dec. 15, 2018.

CURRY; K. HENNEBERRY, D. Agricultural import demand in large markets: an aggregate analysis with high and low growth sub-groups. Journal of Food Products Marketing, 2: 67-87, 1992. Available from: <https:/www.researchgate.net/ publication/34095032>. Accessed: Dec. 15, 2018.

DANMOLA, R.A. Theimpact of exchange rate volatility on the macro economic variables in Nigeria. March 2013 edition vol.9, No.7 ISSN: 1857 - 7881 (Print) e - ISSN 1857- 7431. Available from: $<$ https://pdfs. semanticscholar.org/5f39/e1fc91dacd649825824d765bce3fe760333b. pdf $>$. Accessed: Dec. 15, 2018.

DAWSON, P. J. Agricultural exports and economic growth in less developed countries. Agricultural economics, 33(2): 145-152, 2015. Available from: <https:/www.researchgate.net/ publication/4738350>. Accessed: Dec. 15, 2018.

DICKEY, D. A; FULLER, W. A. Distribution of the estimators for autoregressive time series with a unit root. Journal of the American statistical association, v.74(366a) p.427-431, 1979. Available from: $<$ https://www.researchgate.net/publication/312992058>. Accessed: Dec. 19, 2018. doi: 10.2307/2286348.

EATON, J. Market structure and foreign trade: Increasing returns, imperfect competition and the international economy: Elhanan Helpman and Paul R. Krugman, (MIT Press, Cambridge, MA, 1985). Journal of International Economics, 21(1): 183-187, 1986.

FAO. FAO Statistic for 2016-17. Food agricultureorganization statistic report for the year. Available from: $<$ http://www.fao.org/ economic/est/international-trade/en/>. Accessed: Dec. 12, 2018.

FRIEDEN, J. et al. (2010). The political economy of exchange rate regimes in transition economies. Review of International Organizations, 5(1): 1-25, 2010. Available from: <https:// www.researchgate.net/publication/227304742>. Accessed: Dec. 15, 2018.

FUCHSLOCHER, C. T. The Role and Development of TechnologyIntensive Suppliers in Resource-Based Economies: A Literature Review.Social Science Electronic Publishing., 2007. Available from: $\quad<$ https://www.researchgate.net/publication/5080767>. Accessed: Dec. 12, 2018. doi: 10.2139/ssrn.1029304.

GOP. (2017a). Government of Pakistan. 2016-2017. Finance Division. Economic Adviser's Wing, Islamabad, 2017. Available from: <http://www.finance.gov.pk/>. Accessed: Jul. 22, 2018.

GOP. (2017b). Pakistan Agriculture Research Council Islamabad. Postal address: National Agricultural Research, Centre Park Road, Islamabad - Pakistan: 44000. Available from: <http://www. pbs.gov.pk/content/agriculture-statistics>. Accessed: Dec. 22, 2018. Islamabad - Pakistan: 44000. Accessed: Dec. 12, 2018. 
HATEMI-J, A. Asymmetric causality tests with an application. Empirical Economics, v 43(1) p 447-456, 2012. Available from: $<$ https://ideas.repec.org/a/spr/empeco/v43y2012i1p447-456. html/>. Accessed: Dec. 19, 2018. doi:10.1007/s00181-011-0484-x.

HYE, Q. M. A. Exports, imports and economic growth in China: an ARDL analysis. Journal of Chinese Economic \& Foreign Trade Studies, 5(1): 42-55, 2012. Available from: <https://www. researchgate.net/publication/235271939>. Accessed: Dec. 12, 2018.

INAM, U. S., UMOBONG, E. C. An Empirical Analysis of the Relationship between Exchange Rate Movements and Economic Growth in Nigeria. European Journal of Business and management, ISSN 2222-1905 (Paper) ISSN 2222-2839 (Online) v7, n.30, 2015. Available from: <https://www.iiste.org/Journals/index.php/EJBM/ article/viewFile/26346/26969>. Accessed: Dec. 15, 2018.

IQBAL, M., et al. The Impact of Institutional Credit on Agricultural Production in Pakistan [with Comments]. Pakistan Development Review, 42(4): 469-485, 2003. Available from: $<$ https://www.researchgate.net/publication/24046370 $>$. Accessed: Dec. 15, 2018.

IRSHAD, M. S.; XIN, Q. Determinants of Exports Competitiveness: An Empirical Analysis through Revealed Comparative Advantage of External Sector of Pakistan. Asian Economic \& Financial Review, 7(3): 623-633, 2017. Available from: <https://www. researchgate.net/publication/316406404>. Accessed: Dec. 15, 2018.

JAKOB, B. Impact of Exchange Rate Regimes on Economic Growth. Undergraduate Economic Review: Vol. 12: Iss. 1, Article 11. Available from: <http://digitalcommons.iwu.edu/uer/ vol12/iss1/11>. Accessed: Dec. 15, 2018.

JAWAID, S. T.; RAZA, S. A. Effects of terms of trade on growth performance of India. Economic Modelling, 33(July): 940-946, 2013. Available from: <https:/www.researchgate.net/ publication/259216693>. Accessed: Dec. 15, 2018.

JONGWANICH, J. Real exchange rate overvaluation and currency crisis: evidence from Thailand. Applied Economics, 40(3): 373-382, 2008. Available from: <https://www.researchgate.net/ publication/24076271>. Accessed: Dec. 15, 2018.

KANG, H. S. Agricultural exports and economic growth: empirical evidence from the major rice exporting countries. Agricultural economics, 61(2): 81-87, 2015. Available from: $<$ https://www.researchgate.net/publication/276441307>. Accessed: Dec. 15, 2018.

KARAMELIKLI, H.; KORKMAZ, S. The dynamics of exchange rate pass-through to domestic prices in Turkey. Journal of Business Economics and Finance, 5(1): 39-48, 2016. Available from: $\quad<$ https://www.researchgate.net/publication/299404059>. Accessed: Dec. 12, 2018.

KIM, D.; PERRON, P. Unit root tests allowing for a break in the trend function at an unknown time under both the null and alternative hypotheses. Journal of econometrics 148(1): 1-13, 2009. Available from: <https://www.researchgate.net/ publication/222394279>. Accessed: Dec. 12, 2018.

KRUGMAN, P. Crises: the next generation. Very rough draft prepared for Razin conference, Tel Aviv University, March 25-6, 2001. Available from: <https:/www.researchgate.net/ publication/292492318>. Accessed: Dec. 15, 2018.
LABORDE, D.; MARTIN, W. Agricultural Trade: What Matters in the Doha Round? IFPRI discussion papers 1251, International Food Policy Research Institute (IFPRI). 4(1): 265-283, 2013. Available from: <https:/www.researchgate.net/ publication/314901201>. Accessed: Dec. 12, 2018.

LEVY-YEYATI, E.; STURZENEGGER, F. To float or to fix: evidence on the impact of exchange rate regimes on growth. American economic review, 93(4): 1173-1193, 2003. Available from: <https:// www.researchgate.net/publication/2835768>. Accessed: Dec. 15, 2018.

LI, Y., et al. Research on the Relationship between Foreign Trade and the GDP Growth of East China.Empirical Analysis Based on Causality. Modern Economy, 1(02): 118. Modern Economy 1(02): 118, 2010. Available from: <https:/www.researchgate.net/ publication/277605433>. Accessed: Dec. 15, 2018.

MAZUMDAR, J. Imported machinery and growth in LDCs. Journal of Development Economics, 65(1), 209e224, 2001. Available from: $\quad<$ https://www.researchgate.net/publication/222687032>. Accessed: Dec. 12, 2018.

MIRCHANDANI, A. Analysis of macroeconomic determinants of exchange rate volatility in India. International Journal of Economics and Financial Issues, 3(1), 172-179, 2013. Available from: $\quad<$ https://www.researchgate.net/publication/282606310>. Accessed: Dec. 15, 2018.

MUSTAFA, K., et al. Volatility of Exchange Rate and Export Growth in Pakistan: The Structure and Interdependence in Regional Markets [with Comments]. Pakistan Development Review, 43(4): 813-828, 2004. Available from: <https://www. researchgate.net/publication/24046436>. Accessed: Dec. 12, 2018.

NADEEM, M. Long Run Effect of Technology Spillover through FDI on Economic Growth: A Panel Co-integration Approach.Social Science Electronic Publishing. Available from: <https://www. researchgate.net/publication/228240189_>. Accessed: Dec. 15, 2018.

NOURZAD, F.; POWELL, J. J. The position of agriculture in the Russian Federation - the last two decades development overview. Openness, growth, and development: Evidence from a panel of developing countries. Published version. Scientific Journal of Administrative Development, Vol. 1, No. 1 (Summer 2003). Available from: <https://www.researchgate.net/ publication/253884930>. Accessed: Dec. 15, 2018.

NURINA, S. Analysis of the Effect of Inflation, Interest Rates, and Exchange Rates on Gross Domestic Product (GDP) in Indonesia. Petra Business and Management Review, 2(1), 2016. Available from: <www.globalbizresearch.org/>. Accessed: Dec. 19, 2018.

OJIDE, M. G, et al. Export-led growth hypothesis in Nigeria: Applications of ARDL model and co-integration analysis. Global Journal of Emerging Market Economies, 6(1): 5-13, 2014. Available from: <https://papers.ssrn.com/sol3/papers. cfm?abstract_id=2269067>. Accessed: Dec. 12, 2018.

OJO, E. J., et al. Agricultural export and economic growth in Nigeria: A multivariate Johansen co-integration analysis. International Journal of Arts and Commerce, 3(3): 89-98, 2014. Available from: <https://www.ijac.org.uk/images/frontImages/ gallery/Vol._3_No._3/10.pdf>.Accessed: Dec. 12, 2018.

OMOTOR, D. G., et al. Policy reforms and agricultural exports in Nigeria: An empirical analysis. Singapore Economic Review, 54 
(04): 589-603, 2010. Available from: <https://www.researchgate. net/publication/46510470>. Accessed: Dec. 19, 2018.

RAJAN, R. S. Management of exchange rate regimes in emerging Asia. Review of Development Finance, 2 (2): 5368, 2012. Available from: <https://www.researchgate.net/ publication/228265242>. Accessed: Dec. 19, 2018.

RAZA, S. A., AFSHAN, S. Determinants of Exchange Rate in Pakistan: Revisited with Structural Break Testing. Global Business Review, 18(4), 825-848, 2017. Available from: <https:// www.researchgate.net/publication/291820656_Determinants_of Exchange_Rate_in_Pakistan_Revisited_with_Structural_Break Testing >. Accessed: Dec. 19, 2018.

RAZA, S. A., et al. Energy conservation policies, growth and trade performance: Evidence of feedback hypothesis in Pakistan. Energy Policy, 80: 1-10, 2015. Available from: <https://www.researchgate. net/publication/271388527>. Accessed: Dec. 19, 2018.

RICHARDSON, K. E. et, al. A comparative analysis of the impact of agricultural exports on economic growth of ecowas countries. Oeconomicapragensia, v.24, n05, 2016. Available from: $\quad<$ https://www.researchgate.net/publication/309646858>. Accessed: Dec. 12, 2018.

RODRIK, D. The Real Exchange Rate and Economic Growth. Brookings Papers on Economic Activity, 39(2): 365 412, 2008. Available from: <https://www.researchgate.net/ publication/265709207>. Accessed: Dec. 19, 2018.

SECK, A. International technology diffusion and economic growth: Explaining the spillover benefits to developing countries. Structural Change \& Economic Dynamics, 23(4): 437451, 2012. Available from: <https://www.researchgate.net/ publication/47440910>. Accessed: Dec. 19, 2018.

SHIN, Y et al. Modelling Asymmetric Co-integration and Dynamic Multipliers in a Nonlinear ARDL Framework. Social Science Electronic Publishing, p.281-314, 2014. Available from: $<$ https:// www.researchgate.net/publication/228275564>. Accessed: Dec. 19, 2018. doi: 10.2139/ssrn.1807745.

SHIRAZI, N. S.; MANAP, T. A. A. Export $\square$ led growth hypothesis: Further econometric evidence from South Asia. The Developing Economies, 43(4): 472-488, 2005. Available from: $<$ https://www. researchgate.net/publication/227642018>. Accessed: Dec. 19, 2018.

SHOMBE, N. H. Causality relationships between total exports with agricultural and manufacturing GDP in Tanzania. Institute of developing economies. IDE discussion paper No. 136, 2008. Available from: <https://www.researchgate.net/ publication/5141143>. Accessed: Dec. 12, 2018.

SOKOLOV, V., et al. Linkages between exchange rate policy and macroeconomic performance.Pacific Economic Review, 16(4): 395-420, 2011. Available from: <https://www.researchgate.net/ publication/227697842>. Accessed: Dec. 19, 2018.
SVATOŠ, M., et al. The position of agriculture in the Russian Federation - the last two decades development overview. Agricultural Economics, 60(11): 489-502, 2014. Available from: <https://www.researchgate.net/publication/279106723>. Accessed: Dec. 12, 2018

SVENSSON, L. E. O. Monetary policy and macro prudential policy: Different and separate? Canadian Journal of Economics/ revue Canadienne Déconomique, 51(3): 802-827, 2018. Available from: $\quad<$ https://www.researchgate.net/publication/326759043>. Accessed: Dec. 19, 2018.

SYED A. R. et, al. Determinants of Exchange Rate in Pakistan: Revisited with Structural Break Testing, Global Business Review, 18(4) 1-24, 2017. Available from: <https://www.researchgate.net/ publication/291820656>. Accessed: Dec. 19, 2018.

TAHAR, A. J. et, al. Analysis of Some Drivers of Cocoa Export in Nigeria in the Era of Trade Liberalization. AGRIS on-line Papers in Economics and Informatics, 6(4): 749-823, 2014. Available from: $\quad<$ https://www.researchgate.net/publication/269988493>. Accessed: Dec. 19, 2018.

THANGAVELU, S. M, et, al. Is there an export or import-led productivity growth in rapidly developing Asian countries? A multivariate VAR analysis. Applied Economics, 36(10): 10831093, 2004. Available from: <https:/www.researchgate.net/ publication/24075267>. Accessed: Dec. 12, 2018.

TODA, $H$ et al. Statistical inference in vector autoregressions with possibly integrated processes. Journal of Econometrics, 66(1-2): 225-250, 1995. Available from: $<$ https://www.researchgate.net/publication/223296767>. Accessed: Dec. 19, 2018.

VERTER, N. The Impact of Agricultural Exports on Economic Growth in Nigeria, Acta Universitatis Agricultura e EtSilviculturae Mendeliana e Brunensis, Volume 6481 Number 2, 2016. Available from: < https://acta.mendelu.cz/64/2/0691/>. Accessed: Dec. 12, 2018

WONG, P. K., et al. Entrepreneurship, innovation and economic growth: Evidence from GEM data. Small business economics, 24 (3), 335-350, 2005. Available from: <https://www.researchgate. net/publication/226593748>. Accessed: Dec. 12, 2018.

WITS. World Integrated Trade Solution (WITS) 2017. Available from: <https://wits.worldbank.org/>. Accessed: Dec. 19, 2018.

WTO. World Trade Origination Statistical Review 2017. Available from: <https://www.wto.org/english/res_e/statis_e/ wts2017_e/wts2017_e.pdf>. Accessed: Dec. 12, 2018.

YEAP, G. P.; LEAN, H. H. Asymmetric inflation hedge properties of housing in Malaysia: New evidence from nonlinear ARDL approach. Habitat International, 62: 11-21, 2017. Available from: <https://www.researchgate.net/publication/314113955>. Accessed: Dec. 19, 2018. 